ISSN 2078-6441. Вісник Львівського університету. Серія географічна. 2013. Випуск 42. С. 258-264. Visnyk of the Lviv University. Series Geography. 2013. Issue 42. P. 258-264.

528.942:551.577.21

\author{
лекс ндр кртчян, вло убер \\ ввівський н ціон льний університет імені в н \\ вул. . орошенк 41,79000, ввів, кр їн, \\ e-mail: alemkrt@gmail.com
}

озглянуто особливості інтерполяції зн чень клім тичних елементів методом регресійного кригінгу н прикл ді інтерполяції зн чень річних кількостей оп дів для з хідного регіону кр їни. ведено м тем тичний опис т геогр фічну інтерпрет цію методу регресійного кригінгу, блок-схему лгоритму його з стосув ння, т кож к рти, що ілюструють отрим ні результ ти інтерполяції.

лючові слов : інтерполяція, регресійний кригінг, геоінформ ційний н ліз, клім тичні елементи.

ількість тмосферних оп дів є в жливим клім тичним елементом, що визн ч $є$ н дходження тмосферної вологи н земну поверхню, і однією з головних скл дових водного 6 л нсу території. ому інформ ція про їхній просторовий розподіл необхідн під ч с просторових досліджень водного б л нсу території, водного режиму грунтів і з безпеченості сільськогоспод рських рослин вологою, туристично-рекре ційних ресурсів тощо.

ількість тмосферних оп дів вимірюють дощомір ми, розміщеними н метеорологічних ст нціях т метеопост х. ідповідно, к ртув ння цього пок зник потребує просторової інтерполяції т ких д них. росторов інтерполяція поляг є в передб ченні зн чень деякого клім тичного п р метр у невідомих місцях н підст ві його відомих зн чень у місцях вимірюв нь т (можливо) допоміжної просторово розподіленої інформ ції. ктично, з вд ння інтерполяції - відтворення структури просторового поля певної змінної з зн ченнями цієї змінної (т , можливо, пов'яз них із нею інших змінних) в окремих пункт х цього поля. яз д ч відом т кож як регіон ліз ція д них.

сі методи просторової інтерполяції (регіон ліз ції) поділяють н декільк к тегорій з огляду н фунд мент льні м тем тичні принципи, н яких вони грунтуються. дихотомічними критеріями виділяють т кі к тегорії методів інтерполяції: глоб льні бо лок льні, точні бо н ближені, детерміністичні бо геост тистичні [3].

удоскон ленням технологій геопросторового н лізу д них ефективнішими т вжив нішими вв ж ють геост тистичні методи інтерполяції, які м ють теоретичний 6 зис - теорію регіон лізов ної змінної, т вр ховують імовірнісний (ст тистичний) x p ктер просторових з лежностей [2]. еорія регіон лізов ної змінної, відповідно, спир ється н перший 3 кон геогр фії, сформульов ний мерик нським геогр фом

облером, який стверджує, що “все пов'яз не з усім, проте речі, розт шов ні поряд, пов'яз ні більше, ніж відд лені між собою” [11].

(C) кртчян ., убер ., 2013 
роцедур геост тистичної інтерполяції скл д ється 3 двох ет пів. першому ет пі з допомогою геост тистичного н лізу д них обчислюють емпіричну функцію втокореляції. ї можн зобр зити у вигляді гр фік - в ріогр ми, як відобр ж $є$ 3 лежність між відст нню між пункт ми т пок зником н півдисперсії - половини середньої різниці у зн ченнях між точк ми, які роз'єднує ця відст нь. другому ет пі підбир ють ст нд ртну функцію, форм якої приблизно збіг ється із формою отрим ної емпіричної в ріогр ми, т кож оптим льні п р метри цієї функції. цією функцією продукують м трицю рівнянь кригінгу, розв'язуючи які, можн отрим ти для будь-якої точки простору прогнозов ні зн чення змінної т зн чення похибки прогнозу. тже, одн 3 в гомих перев г цього методу інтерполяції - можливість оцінити похибку інтерполяції для будь-якого місця розт шув ння.

т кі різновиди геост тистичної інтерполяції (кригінгу): простий, універс льний, індик торний, імовірнісний, диз'юнктивний кригінг, т кокригінг, т кож деякі модифік ції ст нд ртної процедури геост тистичної інтерполяції, н прикл д, метод MISH, розроблений горською метеорологічною службою, який використовує трив лі ч сові серії д них для оптиміз ції п р метрів геост тистичних моделей [10].

ля поліпшення якості просторової інтерполяції в б г тьох вип дк х доцільно з стосовув ти допоміжну просторово розподілену інформ цію. дним 3 в жливих джерел т кої інформ ції можуть бути цифрові моделі рельєфу ( ), що містять інформ цію щодо морфології земної поверхні. изк клім тичних п р метрів, зокрем , кількість тмосферних оп дів, відобр ж ють вир жений зв'язок зі зн ченнями висоти н д рівнем моря. рім того, цифровий н ліз д є змогу визн ч ти похідні р строві ш ри, як-от похилів поверхні, експозиції, з г льної, горизонт льної і вертик льної кривизни, горизонт льного і вертик льного розчленув ння поверхні. ізні зн чення п р метрів рухомого вікн д ють змогу обчислюв ти ці морфометричні п р метри н різних просторових (м сшт бних) рівнях. еякі з т ких п р метрів можуть м ти зв'язок 3 х р ктеристик ми лок льного клім ту. прикл д, н вітряне бо підвітряне експозиційне положення щодо до руху вологих повітряних м с вплив є, відповідно, позитивно т нег тивно н кількість тмосферних оп дів. ертик льне розчленув ння поверхні може вплив ти н рівні оп дів через збільшення турбулентності повітряних потоків.

дослідженнях [4, 5] про н лізов но кореляційні з лежності між зн ченнями місячних і річних кількостей оп дів т низкою морфометричних п р метрів. иявлено, що зн чення кореляції відрізняються з лежно від клім тичного елемент т синоптичної х р ктеристики певного місяця чи року. прикл д, для річних кількостей оп дів з 1961 i 1970 pp. н йбільш зн чущими виявилися т кі х р ктеристики рельєфу (у порядку зменшення зн чущості): вертик льне розчленув ння, ф ктор експозиції (з зимутом північний з хід-південний схід), бсолютн висот . обто вплив бсолютної висоти виявився н віть дещо меншим, ніж вплив інших двох похідних морфометричних п р метрів (див. т бл. 1,2).

зн чимо, що вплив рельєфу н деякі клім тичні змінні, як-от кількість тмосферних оп дів, $є$ нелок льним. прикл д, з спостереженнями . ppi, середня висот в р діусі 8 км від місця розт шув ння дощомір $\epsilon$ кр щим предиктором річної кількості оп дів, ніж висот метеост нції [1]. е озн ч є, зокрем, що визн чені з вертик льним гр дієнтом зн чення кількості оп дів для днищ вузьких долин будуть суттєво з ниженими, для вершин вузьких хребтів - з вищеними. елок льні впливи легко моделюв ти у , з стосовуючи фок льні опер тори до відповідних р стрових ш рів. мінюючи р діус рухомого вікн, у якому визн ч ють морфометричні п р метри, 
можн виявляти вплив цих п р метрів н різних просторових рівнях (м сшт б х).

цьому р зі можн підібр ти р діус рухомого вікн , з якого кореляція з клім тичною змінною (н прикл д, кількістю оп дів) буде н йбільшою.

блиця 1

р метри регресійної моделі зв'язку між морфометричними п р метр ми т річною кількістю оп дів, 1961 p. $\left(R=0,9283 ; R^{2}=0,8618\right.$; Adj. $\left.R^{2}=0,8475 ; F(3,29)=60,276\right)$

\begin{tabular}{|c|c|c|c|c|c|c|}
\hline ок зник & Beta & $\begin{array}{c}\text { т нд ртне } \\
\text { відхилення } \\
\text { Beta }\end{array}$ & B & $\begin{array}{c}\text { T нд ртне } \\
\text { відхилення В }\end{array}$ & $\mathbf{t}(29)$ & р-рівень \\
\hline еретин & & & 310,9357 & 17,70883 & 17,55823 & 0,000000 \\
\hline $\begin{array}{c}\text { исот } \\
\text { (вікно 7 км) } \\
\end{array}$ & 0,335891 & 0,122319 & 0,1806 & 0,06577 & 2,74602 & 0,010253 \\
\hline 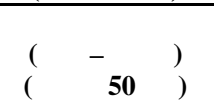 & $-0,220288$ & 0,074394 & $-0,4873$ & 0,16457 & $-2,96110$ & 0,006058 \\
\hline $\begin{array}{c}\text { ертик льне } \\
\text { розчленув ння } \\
\text { (вікно 10 км) }\end{array}$ & 0,525684 & 0,121558 & 1,0329 & 0,23884 & 4,32455 & 0,000165 \\
\hline
\end{tabular}

блиця 2

р метри регресійної моделі зв'язку між морфометричними п р метр ми т річною кількістю оп дів, 1970 p. $\left(R=0,931 ; R^{2}=0,8675 ;\right.$ Adj. $\left.R^{2}=0,8547 ; F(3,31)=67,662\right)$

\begin{tabular}{|c|c|c|c|c|c|c|}
\hline ок зник & Beta & $\begin{array}{c}\text { т нд ртне } \\
\text { відхилення } \\
\text { Beta } \\
\end{array}$ & B & $\begin{array}{c}\text { T нд ртне } \\
\text { відхилення В }\end{array}$ & $\mathbf{t}(\mathbf{3 1})$ & р-рівень \\
\hline еретин & & & 604,6345 & 40,23049 & 15,02926 & 0,000000 \\
\hline $\begin{array}{c}\text { исот } \\
\text { (вікно } 7 \text { кM) }\end{array}$ & 0,221584 & 0,124432 & 0,2524 & 0,14172 & 1,78077 & 0,084752 \\
\hline $\begin{array}{c}\text { кспозиція } \\
\text { ( н - д х) } \\
\text { (вікно 70 км) }\end{array}$ & $-0,305683$ & 0,071872 & $-1,2763$ & 0,30007 & $-4,25314$ & 0,000180 \\
\hline $\begin{array}{c}\text { ертик льне } \\
\text { розчленув ння } \\
\text { (вікно 10 км) }\end{array}$ & 0,565003 & 0,125135 & 2,2790 & 0,50475 & 4,51516 & 0,000086 \\
\hline
\end{tabular}

ші дослідження з свідчили, що для моделюв ння впливу бсолютної висоти н кількість оп дів доцільніше використовув ти її зн чення, усереднене у вікні р діусом 5-10 км. плив н кількість оп дів вертик льного розчленув ння рельєфу н йінтенсивніший у м сшт бі близько 10 км. одо впливу н кількість оп дів м кроекспозиції, то необхідно визн чити ще один п р метр - зимут (румб), що відповід $є$ н йбільшій кореляції. ші дослідження виявили, що з восьми можливих зимутів н йбільш кореляція спостережен 3 зимутом північний з хід - південний схід, тобто н йбільш кількість оп дів вип д $є$ н території з північно-з хідною мезоекспозицією [5]. ей зимут з г лом відповід $є$ н пряму п нівних вітрів, що переносять вологі повітряні м си. ктору експозиції відповід $\epsilon$ морфометричний п р метр, який обчислюють як різницю середньої висоти, визн ченої у північно-з хідному т південно-східному сектор х рухомого кол відповідного р діус .

ля вр хув ння впливу сукупності мофрометричних чинників створюють модель множинної регресії ( $\quad$ ), як м є вигляд: $Y=b_{0}+b_{1} X_{1}+b_{2} X_{2}+b_{3} X_{3}$, де $1, \quad 2, \quad 3-$ морфометричні п р метри: бсолютн висот, вертик льне розчленув ння рельєфу т експозиційний п р метр, відповідно; $b_{0-3}-$ коефіцієнти, визн чені методом н йменших кв др тів. 
етод інтерполяції з використ нням сисоку множинну кореляцію, ре льні зн чення, виміряні н метеост нціях, дещо відрізнятимуться від обчислених 3 для відповідних місць. ш н ліз цих відмінностей (з лишкових відхилень) виявив деякі 3 кономірності. о-перше, ближчі в просторі місця з звич й виявляють менші відмінності в зн ченнях з лишкових відхилень. о-друге, нерідко спостеріг ються широком сшт бні просторові з кономірності (тренди) у цих зн ченнях. прикл д, річні суми оп дів з 1961 р. у цьому регіоні виявляють тенденцію до зменшення в н прямі н північний схід, причому це не з лежить від просторової структури рельєфу. відси виплив $\epsilon$, що точність інтерполяції можн підвищити, доповнивши інтерполяцію методом геост тистичною інтерполяцією з лишкових відхилень регресії, з стосовуючи метод універс льного кригінгу (який водноч с вр ховує просторову втокореляцію д них і просторові тренди).

ропонов ний метод інтерполяції д них відомий як регресійний кригінг [9]. ін передб ч є дв основні ет пи: 1) побудову т обчислення моделі множинної регресії з лежності між $\mathrm{x}$ р ктеристик ми рельєфу т сум ми оп дів бо іншою клім тичною змінною; 2) геост тистичну інтерполяцію з лишкових відхилень кількостей оп дів бо зн чень іншої клім тичної змінної від зн чень, передб чених регресійною моделлю, т дод в ння отрим ного поля до поля зн чень, обчислених 3 . ет льніше цей метод відобр жено н рис. 1.

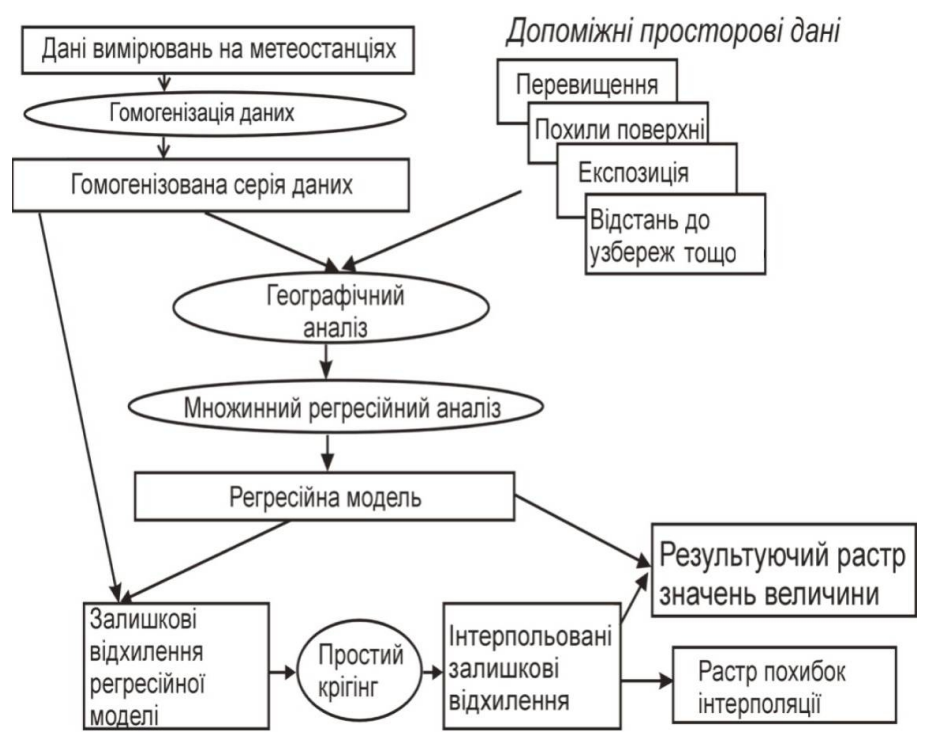

ис. 1. лок-схем інтерполяції д них методом регресійного кригінгу.

тем тичне рівняння моделі регресійного кригінгу м є т кий вигляд:

$$
z\left(s_{0}\right)=m\left(s_{0}\right)+e\left(s_{0}\right)=\sum_{k=0}^{p} \beta_{k} \cdot q_{k}\left(s_{0}\right)+\sum_{i=1}^{n} \lambda_{i} \cdot e\left(s_{i}\right),
$$

де $z\left(\mathrm{~s}_{0}\right)$ - передб чення моделі регресійного кригінгу; $s_{0}-$ пункт, для якого роблять передб чення; $s_{i}$ - пункти метеоспостережень; $m\left(s_{0}\right)$ - детермінов ний член (передб - 
чення $) ; e\left(s_{0}\right)$ - інтерпольов ні з лишкові відхилення; $q_{k}\left(s_{0}\right)$ - зн чення допоміжних змінних (н прикл д, морфометричних п р метрів) у пункті, для якого роблять передб чення; $\beta_{k}$ - оцінки коефіцієнтів детерміністичної моделі (п р метрів ); $\lambda_{i}$ - в ги в моделі кригінгу, оцінені шляхом н лізу структури просторових з лежностей 3 лишкових відхилень; $e\left(s_{i}\right)-3$ лишкові відхилення в пункт х метеоспостережень.

и з стосув ли цю методику для інтерполяції річних сум оп дів для двох років 3 метеост нцій з хідного регіону кр їни. ідповідні д ні метеост нцій оцифров но, місця розт шув ння метеост нцій прив'яз но до геогр фічної системи координ т у середовищі . ля н лізу впливу н метеопок зники морфометричних п р метрів використ но цифрову модель рельєфу SRTM DEM з первинною роздільністю 90 м.

допомогою опер цій - н лізу з неї отрим но низку похідних ш рів морфометричних пок зників, т кож викон но їхню генер ліз цію методом усереднення в рухомому колі. процесі н лізу з стосовув ли прогр мний -п кет ArcView, т кож вільний прогр мний продукт SAGA, розроблений в університеті еттінген ( імеччин ), який м є зн чні н літичні можливості [7].

р метри регресійних моделей ( ), обчислені для річних сум оп дів з 1961 і 1970 pp., н ведені у т бл. 1,2. оефіцієнт множинної кореляції між сукупністю з зн чених чинників т річними кількостями оп дів виявився досить високим: 0,93 для 1961 р. т 0,95 для 1970 р. тже, в обох вип дк х модель пояснює пон д 86 \% просторової в рі бельності зн чень річних кількостей оп дів. е підтверджує, що морфометричні пок зники слугують добрими предиктор ми річних кількостей оп дів і їх можн використ ти для просторової інтерполяції д них метеост нцій т отрим ння просторово розподілених д них (ш рів).

езультуючі к рти розподілу кількостей оп дів зобр жено н рис. 2, 3.
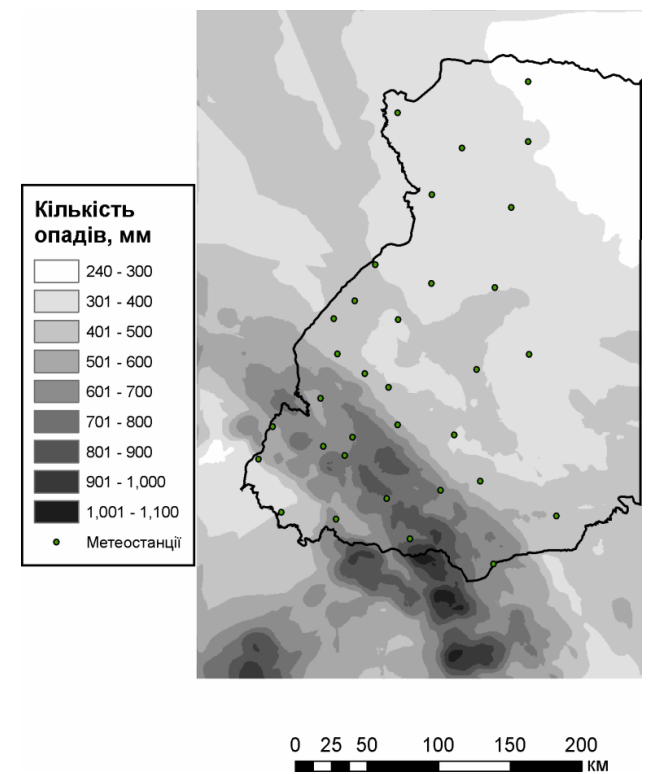

ис. 2. озподіл річної кількості тмосферних оп дів уз хідному регіоні кр їни, 1961 р.
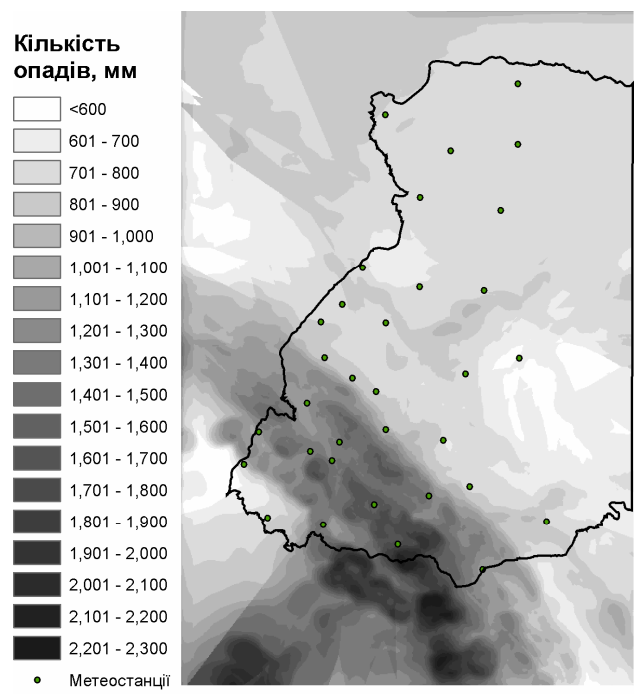

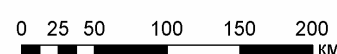
ис. 3. озподіл річної кількості тмосферних оп дів у з хідному регіоні кр їни, 1970 р. 
егресійний кригінг є н йліпшим незміщеним лінійним предиктором для просторових д них, тобто н йліпшим лінійним інтерполятором 3 припушення універс льної моделі просторової в рі ції [9]. снує певний досвід з стосув ння цієї методики для інтерполяції клім тичних д них у різних кр їн х. окрем , в ході досліджень у ольщі виявлено, що результ ти інтерполяції методом регресійного кригінгу середніх місячних i сезонних зн чень темпер тури повітря були точнішими, ніж визн чені іншими метод ми [8]. іншому дослідженні викон но порівняльний н ліз різних методів інтерполяції середньомісячних темпер тур повітря з д ними 84 метеорологічних ст нцій у ортуг лії [12] (вивч ли ефективність використ ння т ких методів, як спл йни, простий кригінг, простий кокригінг, лінійн регресія т нейронні мережі). процесі н лізу з'ясов но, що регресійний кригінг, у якому як предиктори використ но зн чення бсолютної висоти т відст ні до моря, д в меншу середньокв др тичну похибку інтерполяції т н йбільший коефіцієнт кореляції між виміряними і передб ченими зн ченнями порівняно з іншими метод ми [12].

тже, регресійний кригінг є ефективною, оптим льною з погляду м тем тичної ст тистики, пробов ною в низці досліджень методикою інтерполяції клім тичних д них, яку можн використ ти під ч с скл д ння к рт розподілу зн чень клім тичних змінних. окрем, ми т кож використовув ли цей метод для інтерполяції зн чень середньомісячних темпер тур повітря і створення к рт темпер турних полів [6].

1. $р р и$. огод и клим т в гор х / . рри. - ., 1984.

2. терон . сновы прикл дной геост тистики / . ттерон. - . : ир, 1968. $407 \mathrm{c}$

3. кртчян . . еоінформ ційне моделюв ння в конструктивній геогр фії: [н вч. посібник] / . . кртчян. - ьвів : ид вничий центр ім. . р нк , 2010. $120 \mathrm{c}$.

4. кртчян . етодик геопросторового моделюв ння т к ртув ння клім тичних х р ктеристик з д ними спостережень / . кртчян, . убер // існик ьвів. ун-ту. ер. геогр. - 2011. - ип. 39. - . 245-253.

5. кртчян . орівняльний н ліз зв'язків клім тичних х р ктеристик з кількісними морфометричними х р ктеристик ми рельєфу т положенням у л ндш фтній структурі / . кртчян, . убер // існик ьвів. ун-ту. ер. геогр. - 2012. - ип. 40, . 2. - .91-97.

6. кртчян . еоінформ ційне моделюв ння темпер турного поля з хідних регіонів кр їни / . кртчян, . убер // ізичн геогр фія і геоморфологія. - 2009. ип. 57. - . 104-112.

7. Boehner J. SAGA - Analysis and Modelling Applications. / J. Boehner, K.R. McCloy, J. Strobl // Goettinger Geographische Abhandlungen. - 2006. - Vol. 115. - P. 13-27.

8. Dryas I. The Spatial Analysis of the Selected Meteorological Fields in the Example of Poland / I. Dryas, Z. Ustrnul // H. Dobesch et al. (Ed.) Spatial interpolation for climate data: the use of GIS in climatology and meteorology. - London: ISTE Ltd, 2007. P. 87-96.

9. Hengl T. About regression-kriging: From equations to case studies / T. Hengl, G. Heuvelink, D. Rossiter // Computers \& Geosciences. - 2007. - N 33. - P. 1301-1315. 
10. Sluiter $R$. Interpolation methods for climate data. Literature review / R. Sluiter / KNMI intern rapport; IR 2009. - De Bilt, 2009. - 24 p.

11. Tobler W. A computer movie simulating urban growth in the Detroit region / W. Tobler // Economic Geography. - 1970. - N 46 (2). - P. 234-240.

12. Tveito $O . E$. The use of Geographic Information Systems in Climatology and Meteorology / O. E. Tveito, M. Wegehenkel, F.v.d. Wel, H. Dobesch / Final report of COST Action 719, Cost Office, Brussels, EUR 23461. - 2008. - 246 p.

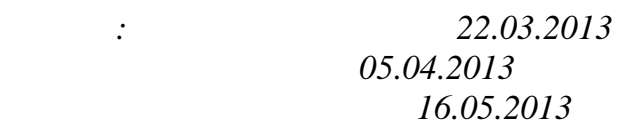

\title{
INTERPOLATION OF METEODATA ON PRECIPITATION AND OTHER CLIMATIC VARIABLES BY REGRESSION-KRIGING
}

\author{
Olexandr Mkrtchian, Pavlo Shuber \\ Ivan Franko National University of Lviv, \\ P. Doroshenko Str., 41, UA - 79000 Lviv, Ukraine, \\ e-mail:alemkrt@gmail.com
}

The paper examines the features of the interpolation of climatic elements by the regression-kriging method, on an example of the interpolation of annual precipitation for the Western Ukraine. The mathematical description and the geographic interpretation of the regression-kriging method are given, together with the block-scheme of its application algorithm, as well as the maps illustrating the obtained interpolation results.

Key words: interpolation, regression-kriging, GIS-analysis, climatic elements.

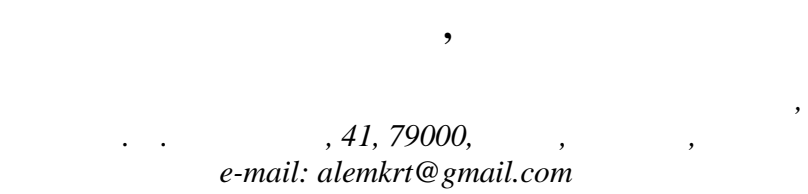

ссмотрено особенности интерполяции зн чений клим тических элементов методом регрессионного кригинг н примере интерполяции зн чений годовых количеств ос дков для з п дного регион кр ины. риведено м тем тическое опис ние и геогр фическую интерпрет цию метод регрессионного кригинг , блок-схему лгоритм его применения, т кже к рты, которые иллюстрируют полученные результ ты интерполяции.

лючевые слов : интерполяция, регрессионный кригинг, геоинформ ционный н лиз, клим тические элементы. 